\title{
FORMULASI DAN AKTIVITAS ANTIOKSIDAN PERONA PIPI DENGAN ZAT PEWARNA ALAMI EKSTRAK AKAR MENGKUDU (Morinda citrifolia L.)
}

\section{FORMULATION AND ANTIOXIDANT ACTIVITY BLUSH ON WITH NATURAL PIGMENT NONI (Morinda citrifolia L.) ROOT EXTRACT}

\author{
Arini Syarifah, Tjiptasurasa, Athalah Chintia Luthfi Saputra \\ Fakultas Farmasi, Universitas Muhammadiyah Purwokerto \\ Jl. Raya Dukuhwaluh, Dukuhwaluh, Kembaran, Purwokerto 53182, Indonesia \\ Email: arinisyarifah@ump.ac.id (Arini Syarifah)
}

\begin{abstract}
ABSTRAK
Akar mengkudu (Morinda citrifolia L.) dapat digunakan sebagai salah satu alternatif pewarna perona pipi dari alam karena mengandung turunan antrakuinon yaitu morindon dan morindin yang merupakan zat warna dan memiliki aktivitas antioksidan. Penelitian ini bertujuan untuk formulasi ekstrak akar mengkudu sebagai zat pewarna alami pada perona pipi dan mengevaluasi aktivitas antioksidan dari produk tersebut. Akar mengkudu diekstraksi dengan metode maserasi menggunakan metanol 1:1 (b/v). selama $2 \times 24$ jam. Seluruh filtrat digabungkan dan dipekatkan dengan menggunakan rotary evaporator. Ekstrak diformulasikan menjadi 3 formula perona pipi dengan konsentrasi 0,2 (F01), 0,4 (F02), dan 0,6 gram/ml (F03). Sediaan perona pipi dievaluasi sifat fisik (uji homogenitas, uji $\mathrm{pH}$, dan cycling test stability) serta aktivitas antioksidannya dengan metode DPPH. Hasil uji homogenitas menunjukkan semua formula homogen. Untuk uji pH didapatkan hasil 6 (F01), 6 (F02), dan 7 (F03). Uji cycling test stability menunjukkan semua formula stabil selama 6 siklus. Nilai IC $\mathrm{C}_{50}$ perona pipi ekstrak akar mengkudu untuk F01, F02, F03, kontrol positif (vitamin C) dan tanpa ekstrak akar mengkudu sebagai kontrol negatif berturut-turut sebesar 25,916 $\pm 0,424$; $22,848 \pm 0,382 ; 18,556 \pm 0,484 ; 14,621 \pm 0,331 ;$ dan 203,683 $\pm 1,121$ ppm. Uji statistik menggunakan ANOVA satu arah dan Post Hoct Test Tukey menunjukkan F03 memiliki aktivitas antioksidan yang tidak berbeda signifikan dengan kontrol positif (vitamin C).
\end{abstract}

Kata kunci: akar mengkudu, aktivitas antioksidan, perona pipi.

\section{ABSTRACT}

Noni (Morinda citrifolian L.) roots can be used as an alternative natural pigments because it contains Morindon and Morindin, both are anthraquinone derivatives, whose vivid color and antioxidant activity. The aims of this research are formulating noni root extract as the natural pigment for blush on and evaluating antioxidant activity of the product. Extraction of noni root was performed using maseration method with methanol for $2 \times 24$ hours. The ratio of plant material to the solvent was 1:1 (w/v). All filtrat were 
collected and concentrated using rotary evaporator. The extract of noni roots was formulated into FO1, F02, and F03, with concentrations of $0.2,0.4$, and $0.6 \mathrm{~g} / \mathrm{ml}$, respectively. The blush ons were evaluated for their physical properties (homogenity test, $\mathrm{pH}$ test, and cycling test stability) and of antioxidant activity using DPPH method. All formulas were homogeneous and their pH values were 6 (F01), 6 (FO2), and 7 (FO3). Cycling test stability study showed that all formulas were stable for 6 cycles. The $I C_{50}$ values of F01, F02, and FO3 in DPPH assay were 25.916 $\pm 0.424,22.848 \pm 0.382$, and $18.556 \pm 0.484 \mathrm{ppm}$, respectively. The $I C_{50}$ values of positive control (vitamin $C$ ) and negative control (blush on without noni roots extract) were $14.621 \pm 0.331$ and $203.683 \pm 1.121 \mathrm{ppm}$. The antioxidant activity of F03 was comparable to that of positive control.

Key words: antioxidant activity, blush on, noni roots. 


\section{Pendahuluan}

Saat ini perkembangan industri kosmetik Indonesia tergolong meningkat. Hal ini terlihat dari peningkatan jumlah pelanggan kosmetik pada tahun 2012 sebesar 14\% menjadi Rp 9,76 triliun dari sebelumnya $R p$ 8,5 triliun (Kemenperin, 2016). Ini mengindikasikan bahwa adanya peningkatan jumlah konsumen yang menggunakan kosmetik. Salah satu jenis kosmetik yang banyak diminati oleh konsumen adalah perona pipi.

Perona pipi berfungsi sebagai kosmetik dekoratif. Perona pipi diminati karena dapat menimbulkan kesan fresh pada konsumen. Zat warna merupakan komponen yang mempunyai peran utama dalam sediaan perona pipi (Tranggono dan Latifah, 2007). Badan Pengawas Obat dan Makanan (BPOM) tahun 2014 menemukan kosmetika, salah satunya adalah perona pipi, yang mengandung bahan yang berbahaya yaitu bahan pewarna Merah K10 (Rhodamin B).

Bahan pewarna Merah K10 merupakan zat warna sintetis yang dilarang, karena zat warna K10 mengandung senyawa karsinogenik dan jika digunakan dalam konsentrasi tinggi dapat menyebabkan kerusakan hati.
Oleh karena itu, penggunaan pewarna alami dibutuhkan sebagai alternatif pengganti zat warna sintetis karena lebih aman dan tidak banyak menimbulkan efek samping yang tidak diinginkan.

Salah satu bahan alam yang dapat digunakan sebagai pewarna pada perona pipi adalah akar mengkudu (Morinda citrifolia L). Akar tanaman mengkudu mengandung turunan antrakuinon yaitu morindon (Gambar 1) dan morindin yang dapat digunakan sebagai pewarna alami (Mulis, 2005). Senyawa ini menghasilkan warna merah dan kuning. Selain itu senyawa antrakuinon pada akar mengkudu bersifat antioksidan aktif kuat dengan $I_{50} 4,19$ ppm (Rudiyansyah et al., 2012).<smiles>Cc1ccc2c(c1Br)C(=O)c1ccc(O)c(Cl)c1C2=O</smiles>

Gambar 1. Struktur morindon (Makam et al., 2014).

Akar mengkudu di masyarakat Indonesia baru digunakan sebagai pewarna batik pada kosenstrasi $34,85 \%$ dari 20 g ekstrak mengkudu (Thomas et al., 2013). Oleh karena itu, dalam penelitian ini akan dilakukan formulasi sediaan perona pipi dengan 
menggunakan zat warna dari ekstrak akar mengkudu serta melakukan evaluasi stabilitas dan uji antioksidan ekstrak akar mengkudu.

\section{Metode Penelitian}

\section{Alat dan Bahan}

Alat yang digunakan untuk ekstraksi adalah erlenmeyer, rotary evaporator (IKA RV 10), cawan porselen, kertas saring, dan waterbath (HHS4). Alat yang digunakan untuk formulasi pada penelitian ini adalah neraca analitik (Matrix), gelas ukur (Pyrex), dan tempat perona pipi. Alat untuk pengujian aktivitas antioksidan adalah erlenmeyer, pipet ukur, pipet tetes, pipet volume, dan spektrofotometer UV-Vis (Shimadzu 1800).

Bahan tumbuhan yang digunakan adalah akar mengkudu yang dikumpulkan dari Desa Kalikudi, Kecamatan Adipala, Kabupaten Cilacap. Bahan yang digunakan untuk formulasi adalah talk, zink stearate, metil paraben, isoprolpil miristat, fragrance, akuades, metanol yang diperoleh dari PT. Brataco.

\section{Jalannya Penelitian}

1. Determinasi tanaman

Determinasi pohon mengkudu dilakukan di Laboratorium Lingkungan, Fakultas Biologi,
Universitas Jenderal Soedirman

(Unsoed).

2. Pembuatan ekstrak

Sampel akar mengkudu dibersihkan dan dikeringkan. Sampel akar kayu mengkudu yang sudah kering dihaluskan sampai menjadi serbuk. Serbuk akar mengkudu sebanyak 300 gram dimaserasi menggunakan pelarut metanol dengan perbandingan 1:1 (b/v) selama $2 \times 24$ jam. Langkah ini dilakukan berulang kali hingga sebagian besar senyawa telah terekstrak. Seluruh filtrat digabungkan dan dipekatkan dengan mengunakan rotary evaporator pada suhu $40-50{ }^{\circ} \mathrm{C}$ sehingga menghasilkan ekstrak kental. Rendemen yang diperoleh kemudian dicatat.

3. Formulasi sediaan perona pipi

Formulasi sediaan dan proses pembuatan perona pipi mengacu pada penelitian Buttler (2000). Komponen formulasinya dapat dilihat pada Tabel 1. Talkum, zink stearate, metil paraben ditimbang lalu dicampur dan digerus dalam mortar bersih hingga homogen dan menjadi partikel yang lembut. Ekstrak metanol akar mengkudu ditambahkan dalam campuran tersebut. Setelah 
tercampur homogen, isopropil

miristat ditambahkan sedikit demi

sedikit dan diratakan selama $15-20$

menit hingga sediaan terdispersi secara sempurna. Sediaan yang telah jadi diletakkan pada wadah yang tertutup.

Tabel 1. Formula sediaan perona pipi ekstrak mengkudu

\begin{tabular}{lccc}
\hline \multicolumn{1}{c}{ Nama bahan } & F01 & F02 & F03 \\
\hline Talkum (gram) & 7,965 & 7,765 & 7,565 \\
Zink stearate (gram) & 0,5 & 0,5 & 0,5 \\
Isopropil miristat (gram) & 0,5 & 0,5 & 0,05 \\
Ekstrak metanol akar mengkudu (gram/ml) & 0,2 & 0,4 & 0,6 \\
Metil paraben (gram) & 0,25 & 0,25 & 0,25 \\
Fragrance (gram) & 0,10 & 0,10 & 0,10 \\
\hline
\end{tabular}

\section{Evaluasi Sediaan}

Evaluasi fisik sediaan perona pipi meliputi terhadap organoleptis sediaan, uji homogenitas warna, uji $\mathrm{pH}$, dan uji stabilitas produk perona pipi ekstrak akar mengkudu.

1. Uji homogenitas warna

Sampel perona pipi dioleskan pada kaca atau bahan transparan lain yang cocok. Sediaan yang dihasilkan diamati tersusun homogen, ditunjukkan dengan tidak terlihat adanya butiran kasar (Bindharawati, 2013).

2. $\mathrm{Uji} \mathrm{pH}$

Uji pH dilakukan menggunakan kertas $\mathrm{pH}$. Kertas $\mathrm{pH}$ dicelupkan pada sediaan perona pipi yang dilarutkan terlebih dahulu pada akuades.
3. Uji stabilitas

Uji stabilitas perona pipi dilakukan menggunakan metode cycling test. Sediaan perona pipi ekstrak mengkudu disimpan pada suhu $4{ }^{\circ} \mathrm{C}$ selama 24 jam lalu dikeluarkan dan ditempatkan pada suhu $40{ }^{\circ} \mathrm{C}$ selama 24 jam. Percobaan ini diulang sebanyak 6 siklus. Kondisi fisik sediaan perona pipi dicatat selama percobaan antara sediaan yang belum dan telah diberi perlakuan (Wulandari, 2016). Kondisi fisik yang diamati yaitu stabilitas warna dan $\mathrm{pH}$.

Uji Aktivitas Antioksidan

1. Penentuan panjang gelombang maksimum DPPH

Larutan DPPH 0,1 mM sebanyak $2 \mathrm{ml}$ dimasukkan ke dalam tabung 
reaksi lalu ditambahkan metanol p.a sebanyak $2 \mathrm{ml}$, dikocok dengan vortex hingga homogen lalu dituang ke dalam kuvet dan diukur serapannya pada panjang gelombang $400-800 \mathrm{~nm}$ dengan menggunakan spektrofotometer UV-Vis. Panjang gelombang yang dipilih adalah panjang gelombang yang memberikan nilai serapan maksimum untuk pengujian aktivitas antioksidan yaitu pada $516 \mathrm{~nm}$

2. Pembuatan larutan pembanding (vitamin C)

Vitamin C ditimbang sebanyak $10 \mathrm{mg}$, kemudian dilarutkan dalam metanol p.a dalam labu ukur $100 \mathrm{ml}$ untuk membuat larutan induk 100 ppm. Kemudian larutan tersebut dibuat konsentrasi 2, 12, 16, 20, dan 24 ppm.

3. Pembuatan larutan uji sediaan perona pipi ekstrak akar mengkudu

Larutan stok dibuat dengan cara masing-masing formula ditimbang sebanyak 100 mg dan dilarutkan dalam metanol p.a hingga $5 \mathrm{ml}$ sehingga diperoleh larutan stok $20000 \mu \mathrm{g} / \mathrm{ml}$, lalu disaring. Filtrat kemudian dibuat seri konsentrasi sebesar 8, 12, 16, 20, dan 24 ppm.
4. Penetapan $I C_{50}$

Sebanyak 2,0 ml masing-masing larutan uji dengan konsentrasi 8, 12, 16, 2, dan 24 ppm ditambahkan 2,0 ml larutan DPPH 0,1 mM, kemudian diinkubasi pada suhu $37^{\circ} \mathrm{C}$ selama 40 menit di dalam tempat gelap. Serapan kemudian diukur pada panjang gelombang maksimum.

Larutan kontrol positif dengan konsentrasi 2, 12, 16, 20, dan 24 ppm ditambahkan 2,0 ml larutan DPPH 0,1 mM kemudian diinkubasi pada suhu $37{ }^{\circ} \mathrm{C}$ selama 40 menit di dalam tempat gelap. Serapan kemudian diukur pada panjang gelombang maksimum $516 \mathrm{~nm}$.

5. Analisis data

Hasil pengamatan organoleptis, uji $\mathrm{pH}$, dan aktivitas antioksidan dari sediaan perona pipi (nilai $I_{50}$ ) dianalisis menggunakan one way ANOVA dengan taraf kepercayaan 95\%. Selanjutnya analisis dilakukan menggunakan Post Hock Test Tukey untuk melihat perbedaan pada masing-masing formula perona pipi ekstrak akar mengkudu dan kontrol positif. Stabilitas dianalisis secara deskriptif. 


\section{Hasil dan Pembahasan}

Determinasi Tanaman

Hasil determinasi tanaman yang dilakukan di Laboratorium Lingkungan, Fakultas Biologi, Universitas Jenderal Soedirman menyatakan bahan tanaman yang digunakan dalam penelitian adalah akar mengkudu (Morinda citrifolia L.) dan merupakan famili dari rubiaceae.

Pembuatan Ekstrak
Ekstraksi akar mengkudu dilakukan dengan metode maserasi dan menggunakan pelarut metanol. Ekstrak kental yang diperoleh sebanyak 40,74 gram dengan rendemen sebesar $2,03 \%$.

\section{Perona Pipi Ekstrak Akar Mengkudu}

Hasil Formulasi sediaan perona pipi yang dihasilkan memiliki bentuk, warna, dan rasa yang dipaparkan pada Tabel 2.

Tabel 2. Hasil formulasi perona pipi

\begin{tabular}{cccc}
\hline Perona Pipi & Bentuk & Warna & Bau \\
\hline F01 & Serbuk & Pink kecoklatan & Khas minyak mawar \\
F02 & Serbuk & Orange kecoklatan terang & Khas minyak mawar \\
F03 & Serbuk & Orange kecoklatan & Khas minyak mawar \\
\hline
\end{tabular}

\section{Evaluasi Sediaan}

1. Uji homogenitas

Hasil uji homogenitas pada perona pipi dengan ekstrak akar mengkudu sebagai pewarna alami tercampur secara merata dalam formulasi dengan penyusun lainnya. Tidak terdapat butiran ekstrak yang menonjol atau kasar pada produk sediaan perona pipi dengan ekstrak akar mengkudu pada kaca bening.

Syarat homogenitas warna yang baik yaitu zat warna harus terbagi rata di dalam pembawa serbuk sehingga zat warna yang ditambahkan dapat memberikan karakteristik fisik yang baik pada kosmetik dekoratif yang dibuat (Bindharawati, 2013), sehingga dapat dikatakan perona pipi ini sudah memenuhi syarat homogenitas warna yang baik.

2. Uji pH

Pengukuran $\mathrm{pH}$ dilakukan untuk mengamati adanya perubahan $\mathrm{pH}$ yang mungkin terjadi karena adanya keterkaitan $\mathrm{pH}$ dengan stabilitas zat aktif dan efektifitas pengawet. Tabel 3 menunjukkan bahwa $\mathrm{pH}$ sediaan perona tidak bermasalah karena 
berada dalam rentang $\mathrm{pH}$ kulit yaitu 4,5-7 (Wasitaatmadja, 1997).

3. Stabilitas perona pipi

Stabilitas perona pipi dapat dilihat dari stabilitas warna dan $\mathrm{pH}$ (Tabel 4 dan 5). Pada stabilitas warna, perona pipi tidak mengalami perubahan warna sampai siklus ke 6 . Hal ini menandakan bahwa perona pipi stabil terhadap perubahan suhu.
Pengukuran $\mathrm{pH}$ dilakukan untuk mengamati adanya perubahan $\mathrm{pH}$ yang mungkin terjadi karena adanya keterkaitan $\mathrm{pH}$ dengan stabilitas zat aktif dan efektifitas pengawet. Dari hasil yang didapatkan dapat diambil kesimpulan stabilitas $\mathrm{pH}$ sediaan perona pipi stabil karena berada dalam rentang $\mathrm{pH}$ kulit yaitu $(4,5-7)$ (Wasitaatmadja, 1997).

Tabel 3. Hasil uji pH formula perona pipi

\begin{tabular}{cc}
\hline Formulasi Perona Pipi & pH \\
\hline Kontrol negatif & 6 \\
F01 & 6 \\
F02 & 6 \\
F03 & 7 \\
\hline
\end{tabular}

Tabel 4. Hasil uji stabilitas warna

\begin{tabular}{ccccccc}
\hline $\begin{array}{c}\text { Formulasi } \\
\text { Perona pipi }\end{array}$ & Siklus 1 & Siklus 2 & Siklus 3 & Siklus 4 & Siklus 5 & Siklus 6 \\
\hline F01 & PPK & PPK & PPK & PPK & PPK & PPK \\
F02 & OK terang & OK terang & OK terang & OK terang & OK terang & OK terang \\
F03 & OK & OK & OK & OK & OK & OK \\
\hline
\end{tabular}

Keterangan: PPK=pink pucat kecoklatan, OK terang=orange kecoklatan terang, OK=orange kecoklatan

Tabel 5. Hasil uji stabilitas $\mathrm{pH}$

\begin{tabular}{ccccccc}
\hline Formulasi & \multicolumn{6}{c}{ pH } \\
\cline { 2 - 7 } Perona Pipi & Siklus 1 & Siklus 2 & Siklus 3 & Siklus 4 & Siklus 5 & Siklus 6 \\
\hline F01 & 6 & 6 & 6 & 6 & 6 & 6 \\
F02 & 7 & 6 & 6 & 6 & 6 & 6 \\
F03 & 7 & 7 & 7 & 7 & 7 & 7 \\
\hline
\end{tabular}

\section{Uji Aktivitas Antioksidan}

Aktivitas antioksidan dari sediaan perona pipi dianalisis dengan menggunakan metode DPPH. Metode ini merupakan metode yang paling sering digunakan dalam analisis antioksidan 
karena mudah dan dapat mengukur kapasitas antioksidan secara keseluruhan pada suatu sampel (Kurniawan, 2011).

1. Penentuan panjang gelombang

$$
\text { Pada penentuan panjang }
$$
gelombang maksimum DPPH dengan spektrofotometer UV-Vis pada rentang 400-800 $\mathrm{nm}$ diperoleh panjang gelombang DPPH adalah 516 nm dengan nilai absorbansi 0,7718.

2. Penetapan $\mathrm{IC}_{50}$

Hasil penentuan antioksidan kontrol positif, kontrol negatif, F01, F02, dan F03 dapat dilihat pada Tabel 6. Konsentrasi vitamin C yang mampu menghambat radikal bebas sebesar $50 \%$ yaitu sebesar 14,621 ppm. Semakin tinggi aktivitas antioksidan suatu sampel maka semakin rendah nilai $I_{50}$ nya. Suatu senyawa dikatakan memiliki aktivitas antioksidan sangat kuat bila nilai $\mathrm{IC}_{50}<50$ ppm, kuat bila IC $\mathrm{I}_{50}$ bernilai 50 100 ppm, sedang dengan nilai $I_{50}$
100-150 ppm, dan lemah bila nilai $I C_{50}>150$ ppm (Molyneux, 2003). Berdasarkan penjelasan tersebut, dapat disimpulkan bahwa vitamin C sebagai kontrol positif memiliki aktivitas antioksidan yang sangat kuat karena nilai $I C_{50}<50$ ppm.

Setelah penentuan aktivitas antioksidan dari kontrol positif, dilakukan penentuan aktivitas antioksidan untuk kontrol negatif dan formulasi sediaan perona pipi dengan berbagai konsentrasi. Dari hasil $I_{50}$ F01, F02, dan F03 yang didapatkan dari hubungan \% penghambatan (y) dengan konsentrasi $(x)$, didapat kesimpulan bahwa semakin besar konsentrasi ekstrak akar mengkudu yang ditambahkan dalam formulasi sediaan perona pipi semakin kecil nilai $\mathrm{IC}_{50}$ yang didapat, nilai $\mathrm{IC}_{50}$ kecil menandakan kandungan antioksidannya sangat kuat karena nilai IC $C_{50}<50$ ppm.

Tabel 6. Nilai penetapan $\mathrm{IC}_{50}$

\begin{tabular}{lc}
\hline \multicolumn{1}{c}{ Kelompok Uji } & IC $_{50}(\mathbf{p p m}) \pm$ SD \\
\hline Kontrol negatif & $203,683 \pm 1,121$ \\
Vitamin C & $14,621 \pm 0,331$ \\
Formula I & $25,916 \pm 0,424$ \\
Formula II & $22,848 \pm 0,382$ \\
Formula III & $18,556 \pm 0,484$ \\
\hline
\end{tabular}


Data hasil uji ini selanjutnya dianalisis menggunakan uji ANOVA, dikarenakan data terdistribusi normal dan homogen. Hasil analisis menunjukkan bahwa pada masingmasing formula terdapat perbedaan nilai $I_{50}$ yang signifikan yaitu 0,004 $(p \leq 0,05)$. Selanjutnya analisis dilakukan menggunakan Post Hock Test Tukey untuk melihat perbedaan pada masing-masing formula perona pipi ekstrak akar mengkudu dan kontrol positif. Hasil analisis menunjukkan bahwa dari 3 formula tersebut yang terdapat perbedaan signifikan dari kontrol positif adalah F01 dan F02 dimana nilai IC 50 F01 dan F02 lebih besar dibandingkan dengan kontrol positif. Pada F03 tidak terdapat perbedaan signifikan dengan kontrol positif. Pada F01, F02, dan F03 terdapat perbedaan signifikan dengan kontrol negatif. Hal ini menunjukkan bahwa perbedaan konsentrasi ekstrak akar mengkudu pada sediaan perona pipi dapat mempengaruhi aktivitas antioksidannya yang dilihat dari nilai $I_{50}$. Perona pipi yang mempunyai aktivitas antioksidan terbesar yaitu pada F03 karena mempunyai nilai $\mathrm{IC}_{50}$ yang paling rendah dari formulasi yang lain dan memiliki nilai $I_{50}$ yang tidak berbeda dengan kontrol positif.

\section{Simpulan}

Ekstrak metanol akar mengkudu dapat diformulasikan sebagai zat pewarna pada perona pipi. Formulasi perona pipi ekstrak akar mengkudu mempunyai stabilitas yang baik dilihat dari hasil uji stabilitas warna, $\mathrm{pH}$, homogenitas, dan uji organoleptis sediaan perona pipi ekstrak akar mengkudu. Kandungan antioksidan yang terkandung pada produk perona pipi dengan pewarna berupa ekstrak akar mengkudu mempunyai nilai $\mathrm{IC}_{50}$ pada 25,916 (F01); 22,848 (F02); dan 18,556 ppm (F03) yang berarti termasuk antioksidan kategori sangat kuat yaitu mempunyai nilai $\mathrm{IC}_{50}<50 \mathrm{ppm}$.

\section{Daftar Pustaka}

Bindharawati, N. 2013. Formulasi sediaan pemerah pipi dari ekstrak kelopak bunga rosella (Hibiscus sabdariffa Linn.) sebagai pewarna dalam bentuk compact powder. Skripsi. Fakultas Farmasi, Universitas Katolik Widya Mandala Surabaya.

Buttler, H. 2000. Puncher's, Perfumes, Cosmetics and Soaps. Edisi ke10. London: Kluwer Academic Publisher. 
Kemenperin RI. 2016. Indonesia lahan subur industri kosmetik. http://kemenperin.go.id/artikel/ 5897/Indonesia-Lahan-SuburIndustri-Kosmetik. Data diakses pada 8 November 2017.

Kurniawan, A. 2011. Aktivitas antioksidan dan proteksi hayati dari kombinasi ekstrak empat jenis tanaman obat Indonesia. Skripsi. FMIPA, IPB.

Makam, N.S., Chidambara, Murthy, K.N.C., Sultanpur, C.M., Rao, R.M. 2014. Natural molecules as tumour inhibitors: promises and prospects. Journal of Herbal Medicine, 4:175-187.

Molyneux, P. 2003. The use of stable free radical diphenylpicrylhydrayl (DPPH) for estimating antioxidant activity. Journal of Science and Technology, 26:211-219.

Mulis, D. 2005. Perubahan sifat fisika dan kimia kain sutera akibat pewarna alami kulit akar pohon mengkudu (Morinda Citrifolia). Skripsi. Fakultas Teknik, Universitas Indonesia.
Rudiyansyah, Lang, C.L., Gusrizal, dan Alimuddin, A.H. 2012. Senyawa antrakuinon yang bersifat antioksidan dari kayu akar tumbuhan mengkudu (Morinda citrifolia). Bulletin of the Indonesian Society of Natural Product Chemistry, 12(1):9-13.

Tranggono, R.I. dan Latifah, F. 2007. Buku Pegangan IImu Pengetahuan Kosmetik. Jakarta: Penerbit Pustaka Utama.

Thomas, M., Manurung, M., Asih, I.A.R.A. 2013. Pemanfaatan zat warna alam dari ekstrak kulit akar mengkudu (Morinda citrifolia Linn.). Jurnal Kimia, 7(2):119126.

Wulandari, P. 2016. Uji stabilitas fisik dan kimia sediaan krim ekstrak etanol tumbuhan paku (Nephrolepis falcate (Cav.) C. Chr.). Skripsi. Program Studi Farmasi, Fakultas Kedokteran dan IImu Kesehatan, UIN Syarif Hidayatullah.

$\begin{array}{ccc}\text { Wasitaatmadja. } & 1997 . & \text { Penuntun } \\ \text { Kosmetik } & \text { Medik. } & \text { Jakarta: } \\ \text { Universitas Indonesia. } & \end{array}$ 